\title{
SELF-ASSESSMENT OF SOME TEACHER COMPETENCIES FOR WORKING WITH CHILDREN WITH DISABILITIES
}

\author{
SANDRA KADUM \\ Faculty of Educational Sciences, University Juraj Dobrila of Pula, \\ Ivana Matetića Ronjgova 1, 52100 Pula, Croatia \\ E-mail address: skadum@unipu.hr \\ ORCID ID: 0000-0002-8441-0896 \\ MIRJANA RADETIĆ-PAIĆ \\ Faculty of Educational Sciences, University Juraj Dobrila of Pula, \\ Ivana Matetića Ronjgova 1, 52100 Pula, Croatia \\ E-mail address: miradet@unipu.hr \\ ORCID ID: 0000-0002-5256-724X
}

\begin{abstract}
Aim. The aim of this study is to define teacher competencies and some specific differences in self-assessment with regard to the completion of studies according to the new or the old curriculum. Efforts were also made to gain insight into the specific deficiencies of the competencies related to the integrated education and training of children with developmental disabilities.

Methodology. The research was conducted on a sample of 212 regular primary school teachers who dealt with children with disabilities in their work. A questionnaire constructed for the purposes of this research was used. Previously, a pilot study was conducted. Participants were divided into two groups. One group of teachers who were educated according to the old program and teachers who were educated according to the new program in the broad context of working with children with disabilities.

Results. The obtained results indicate differences between the observed groups and the need for continuous (self) assessments of teachers' responsibilities to enable students with disabilities to learn and thrive in line with their abilities as well as to find alternative ways to meet their different needs in a wider sense. Also, teachers are aware of the need for continuous training in this area. These findings have contributions in the scientific and practical sense.

Key words: students with developmental disabilities, competencies, teachers, selfassessment, lifelong education
\end{abstract}




\section{INTRODUCTION}

Tn the context of the European Qualifications Framework, competencies are, lamong others, responsibility and autonomy of the individual. Those competencies indicate the ability to apply knowledge, skills, as well as personal, social, and methodological abilities in the workplace or during learning, both in private and professional development. The key competencies are those which are necessary for all individuals for personal confirmation and development, active citizenship, social integration, and employment (European Parliament, 2006).

A person can be defined (Kaslow, 2004) as qualified to perform a particular job, and the definition of competence itself includes motivation and action to achieve some degree of qualification. Competencies refer to the ability of an individual to understand and perform certain tasks adequately and efficiently, in accordance with the expectations people have of him/her as a professional qualified in a certain area.

In recent years, in regular education, the schools are facing new challenges in working with students with disabilities (Đuranović, Klasnić, \& Lapat, 2013; Bouillet \& Kudek Mirošević, 2015; Nketsia, 2016). Numerous questions and dilemmas are emerging that require a scientific and professional reflection of all participants in the educational process, as well as other subjects which are directly or indirectly associated with these challenges (Đuranović, Klasnić \& Lapat, 2013).

Research indicates (Gallagher \& Malone, 2009; Milenović, 2011; Ivančić \& Stančić, 2013; Zrilić, 2013) that many teachers feel that they are not sufficiently prepared to support students with disabilities in regular education. They have many dilemmas, for example, regarding professional competencies, motivation, adequate professional and other support etc. Also, the research of Zrilić and Marin (2019) on the development of professional competencies of Croatian teachers from their own perspective, shows how teachers consider themselves competent to work in a modern school and strive for continuous improvement and lifelong learning, because they have no knowledge about all the developmental disabilities. This is particularly important given that the level of support for individualised teaching methods for students with disabilities is closely related to teachers' attitudes towards the inclusion of disadvantaged students into the regular education system (Monsen, Ewing, \& Kwoka, 2014).

On the other hand, some authors (Smole \& Vršnik Perše, 2018; Radetić-Paić, 2018; Zrilić \& Marin, 2019) came up with conclusions which indicate that a relatively large number of teachers still pointed to the problem of insufficient personal knowledge in the field of work with students with special needs as well as developmental disabilities in primary school. They conclude that teachers and professional associates should be more involved, both in the problem of identification and a systematic additional further education and advanced training. Also, they state that teachers point out difficulties in teaching when it comes to introducing innovations to work with students with disabilities. 
Igrić (2015) states that in the beginning, there is uncertainty and resistance among teachers, especially those who meet students with disabilities in their classroom for the first time. Over time, teachers gain a sense of self-confidence and professional competence not only in lower education but also in higher grades (Sadler, 2013).

It can be concluded that the education of students with disabilities requires a change of the role of a teacher in developing programs and strategies for students with disabilities as well as the availability and cooperation with the educational rehabilitator (Igrić, 2015).

Teachers should also have specific competencies (Vizek Vidović, 2009), which are particularly important in planning and implementing individualised approaches to work with students with disabilities. In this context, different competencies are important such as dedication to encouraging student achievement and progress, development and support of learning strategies and counselling of students and parents. Also, it is important, among others, to create a learning-friendly environment with the possibility of applying what has been learned. At the end it is important to adapt the curriculum to the specific context of education. In inclusive education of children with special needs, the role of teachers is crucial, because they take care of the inclusive climate in the classroom and proper teaching with adaptations in the process of teaching and learning (Kovač, Ščuka, \& Čangran, 2017).

Teachers need to be reflexive practitioners who know certain methods of teaching or activities that can stimulate the creativity of their students, create a better contribution to personalised learning and acquiring new skills (The Strategy of Professional Training for the Professional Development of Educational Workers, 2014-2020). Namely, studies in the educational practice (Kovač, Ščuka, \& Čangran, 2017; Baguisa \& Ang-Manaig, 2019) found that the quality of the educational process depends on the manifestation of teachers' professional competencies that significantly contribute to the way students behave, which includes knowledge, skills, and attitudes related to integrated education. Teachers must avoid prejudices, manage their own expectations for children with disabilities, and focus on positive assessment of strong areas of children with disabilities in different areas. Finally, a change of focus by teachers is needed by incorporating playful and concrete activities into their methodological practices, based on the suggestions issued by all participants in this process (Tome, 2021).

\section{METHODOLOGY}

Objectives, hypothesis and purpose of the research

The aim of the research is to gain insight into the assessment of a teacher's own competencies and to establish specific differences in their self-assessments with regard to the old and new study curriculum. The purpose of the research was also to gain insights into the specific skills shortages associated with the integrated education and training of students with disabilities. Given the 
objective and the purpose of the research, the zero hypothesis was set that we defined in the following way:

$\mathrm{H}_{0}$ : Regardless of the completed study curriculum - old or new - teachers equally assess personal competencies regarding the integrated education and training of students with developmental disabilities.

The hypothesis is based on the following assumptions:

1) teachers who completed the studies according to the new curriculum have competencies of higher quality since the curriculum is richer in content; what is more, during their studies, they were more engaged in working with students with disabilities due to a more frequent integration (RadetićPaić, 2018);

2) teachers who completed the studies according to the old curriculum have more experience in direct work with this type of students (Radetić-Paić, 2018).

Namely, the old program, valid before 2005, included shorter professional teacher education programs. The new program, according to the European Commission guidelines and the Bologna Reform in the Croatian education system, raised teacher education to the master university level, which includes, among other things, a larger number of subjects related to working with children with disabilities, but also a higher level and quality of knowledge.

\section{RESEARCH SAMPLE}

The research sample consisted of 212 teachers. The study involved $97.5 \%$ female and $2.5 \%$ male participants. $38.6 \%$ of teachers completed the study under the old curriculum and those who finished the study according to the new curriculum amounted to $61.4 \%$. The research was conducted among teachers of eight regular primary schools in Croatian Istrian County through an online questionnaire. During the research, all ethical standards were respected. With the help of school administration, all participants were informed of the goal of the research and given the instructions on how to fill in the questionnaire and use the data for strictly scientific purposes. Completion of the questionnaire was anonymous and voluntary and participants could give up answering at any time.

\section{MEASURING INSTRUMENT}

The study used an instrument designed precisely for the purpose of this research, which was previously subjected to a pilot-study on a smaller sample (Goldin, 2017).

In order to determine the suitability of the measuring instrument for the study, a factor analysis was performed, preceded by a data validity test for 
the factor analysis. The verification showed that the data are suitable for the application of the factor analysis. Namely, the following values were obtained: according to the Kaiser-Meyer Olkin's test $(\mathrm{KMO}=.85)$ and the Bartlett's sphericity test $\left(x^{2}\right)(190)=3598.5, p<.001$.

Furthermore, the validation of the instrument was performed, and the results of the confirmatory factor analysis of the instrument (20 items) indicate a four-factor solution that explains $69.68 \%$ of the variance. The factors are the following: knowledge, skills, attitudes, and readiness. The reliability of the skills scale $(a=.72)$, attitudes $(a=.86)$, and readiness $(a=.91)$ is satisfactory; the value of the knowledge scale has low reliability, which is $a=.23$.

The descriptive data indicate a negative asymmetry of distribution of the results on all factors, which may indicate low sensitivity of the instrument.

In the final version, the measuring instrument consisted of 20 items (see Table 1 ) evaluated by a five-degree Likert type scale ( 1 = I completely disagree, 2 = I partially disagree, 3 = I cannot decide, $4=\mathrm{I}$ partially agree, and $5=\mathrm{I}$ completely agree).

\section{RESULTS AND DISCUSSION}

At the descriptive level, the arithmetic means of the answers of the teachers who completed the studies according to the new, richer curriculum and those who completed the studies according to the old curriculum (Table 1) show that the first group of teachers present a higher level of agreement with the almost all offered statements except for the statements: 1: "I consider myself sufficiently educated to teach students with developmental disabilities" and 4: "I am ready to accept one student with developmental disabilities in my class", in which the higher degree of agreement was expressed by the teachers who completed the studies according to the old curriculum. The highest degree of agreement is visible with the statement 3: "In my opinion, teachers are offered enough opportunities for further education for teaching students with developmental disabilities", while the highest degree of disagreement is related to the statement 9: "I believe that students with severe hearing loss can be part of a regular class section". It can also be noticed that the greatest dispersion of the results is visible with the statement 20: "I am ready to accept a student with behavioural disorder in my class" and the statement 5: "I am ready to accept more than one student with developmental disabilities in my class", whereas the lowest dispersion of the results may be observed with the statement 6: "I know how to use didactic tools and aids in teaching students with developmental disabilities". 


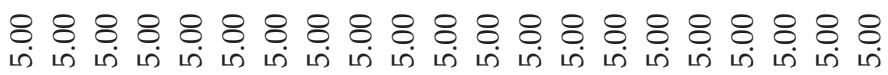

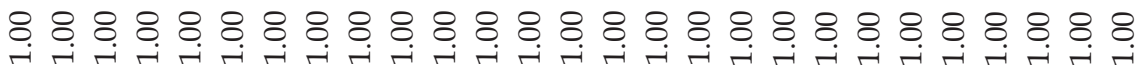

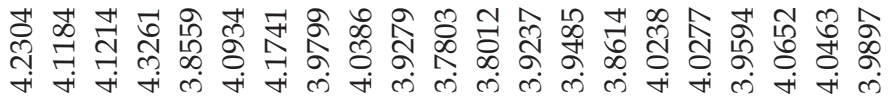

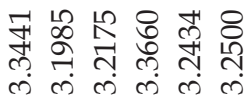

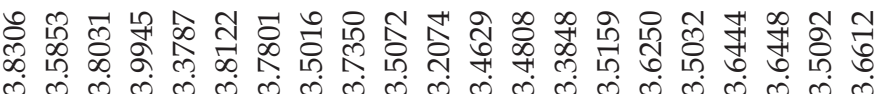

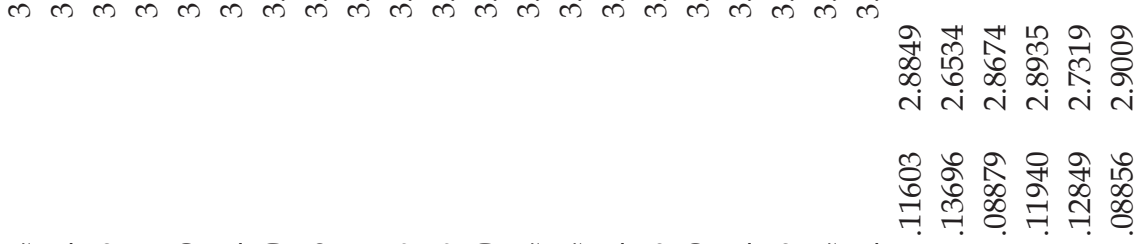

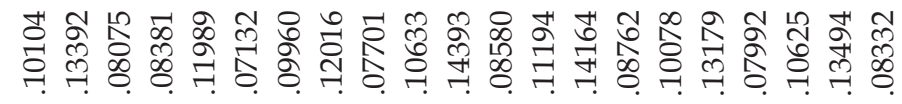

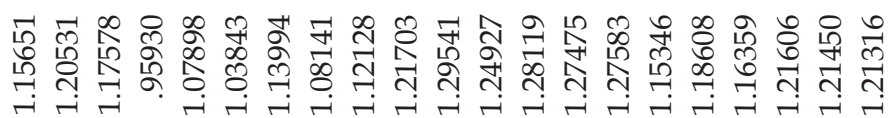

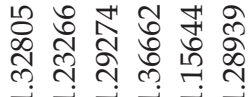

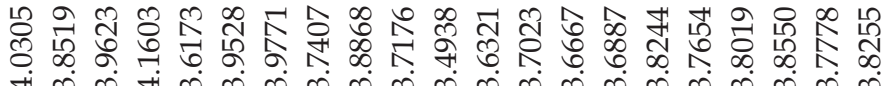

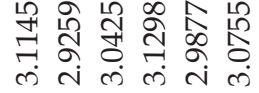

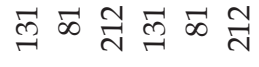

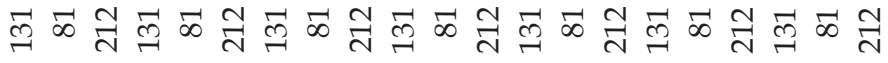

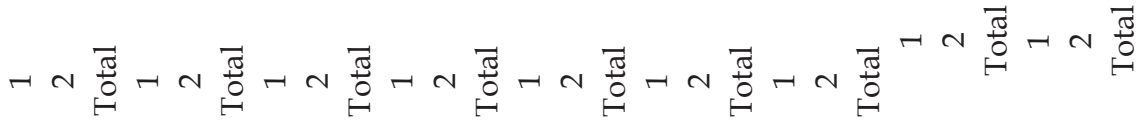

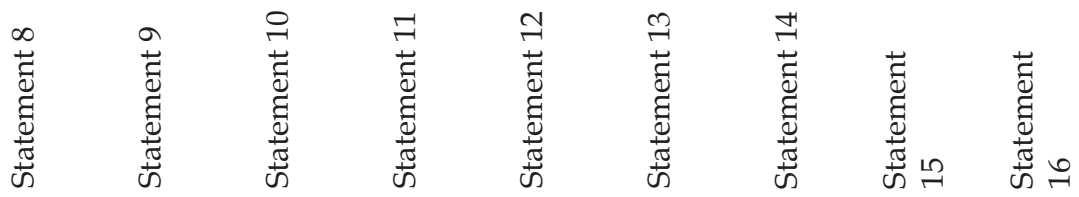




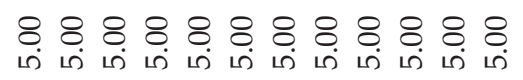

\&

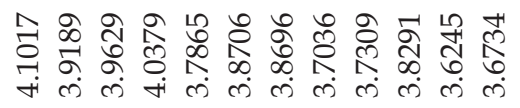

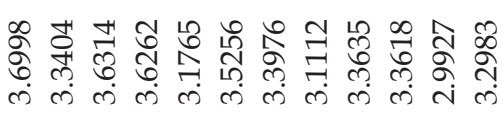

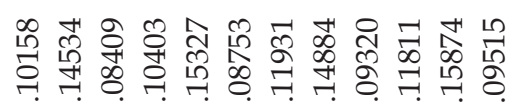

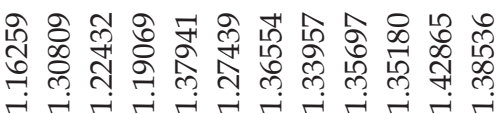

$\begin{array}{llll} & & & \\ 0\end{array}$

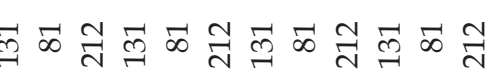
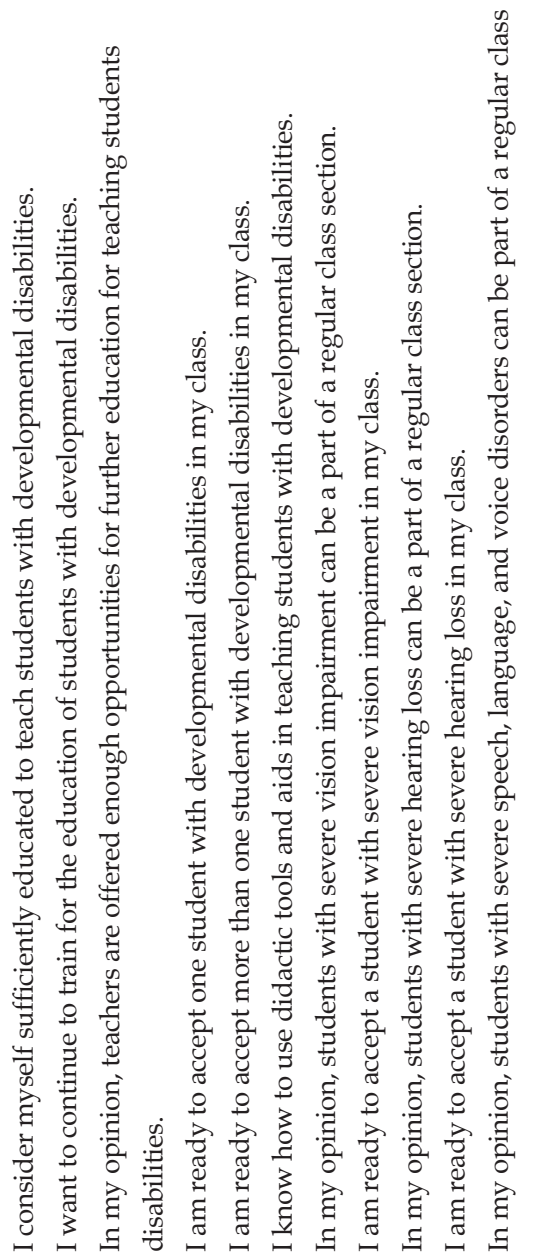

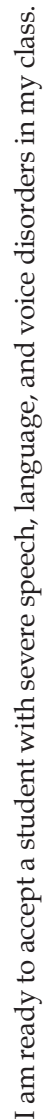

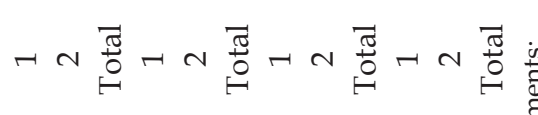

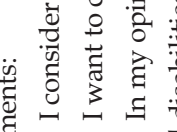

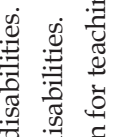

戞

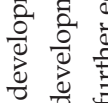

若声总

贾

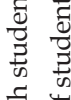

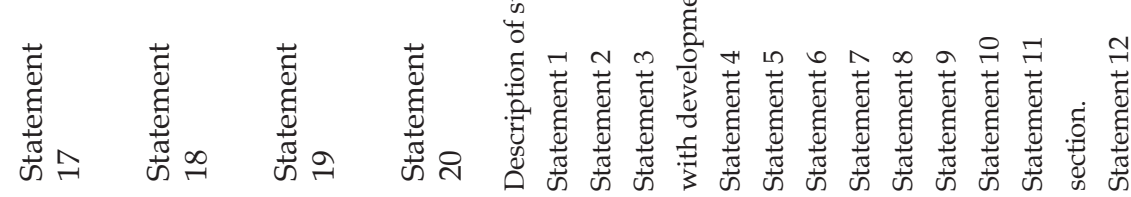




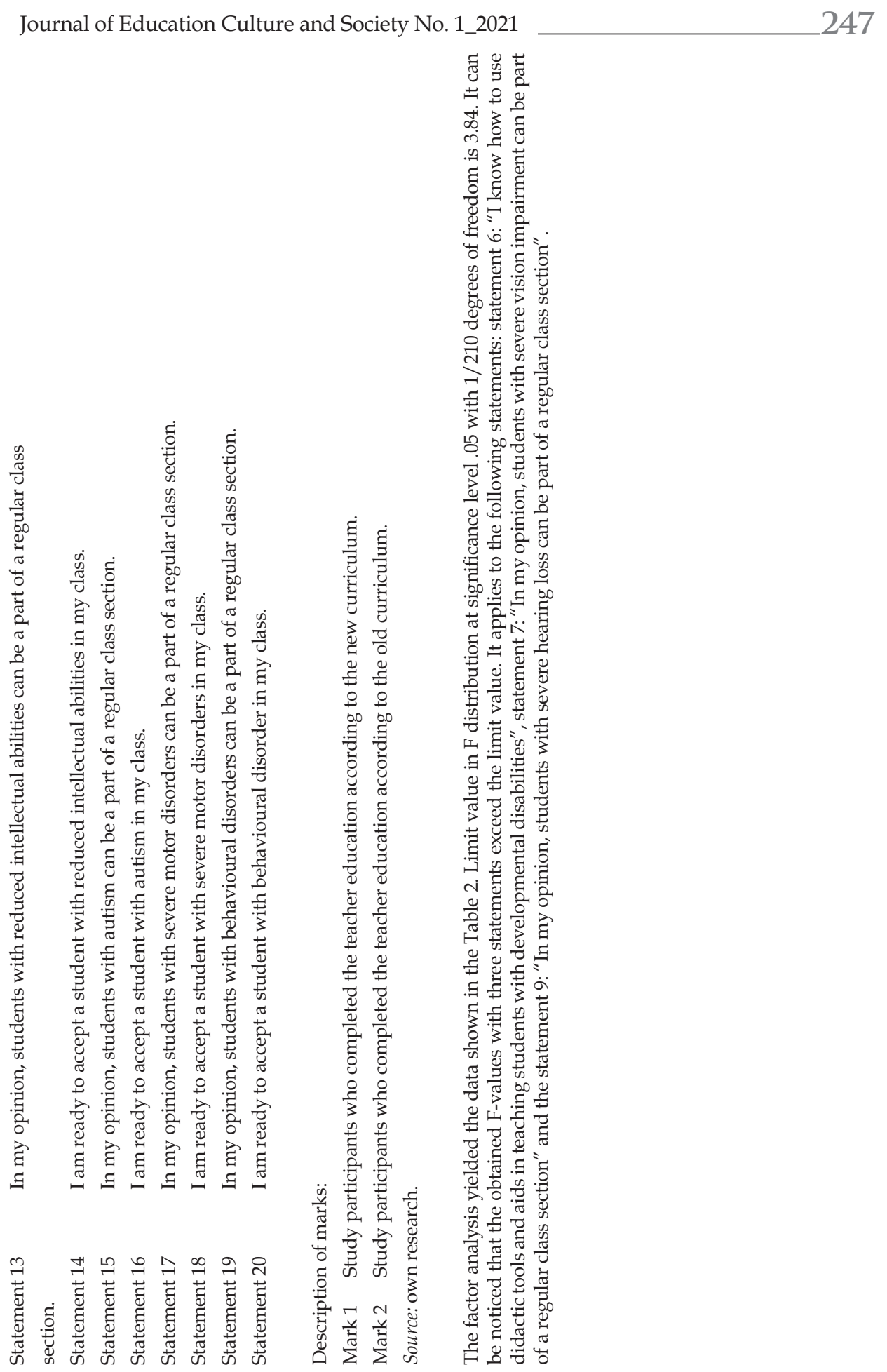


Table 2.

The data obtained by factor analysis

\begin{tabular}{|c|c|c|c|c|c|c|}
\hline & & $\begin{array}{r}\text { Sum of } \\
\text { Squares }\end{array}$ & df & $\begin{array}{r}\text { Mean } \\
\text { Square }\end{array}$ & $\mathrm{F}$ & Sig. \\
\hline \multirow{3}{*}{ Statement 1} & Between Groups & 5.659 & 1 & 5.659 & & \\
\hline & Within Groups & 317.624 & 210 & 1.512 & 3.742 & .054 \\
\hline & Total & 323.283 & 211 & & & \\
\hline \multirow[t]{3}{*}{ Statement 2} & Between Groups & .090 & 1 & .090 & & \\
\hline & Within Groups & 219.131 & 210 & 1.043 & .087 & .769 \\
\hline & Total & 219.222 & 211 & & & \\
\hline \multirow[t]{3}{*}{ Statement 3} & Between Groups & .030 & 1 & .030 & & \\
\hline & Within Groups & 243.908 & 210 & 1.161 & .026 & .872 \\
\hline & Total & 243.939 & 211 & & & \\
\hline \multirow[t]{3}{*}{ Statement 4} & Between Groups & .816 & 1 & .816 & & \\
\hline & Within Groups & 281.047 & 210 & 1.338 & .610 & .436 \\
\hline & Total & 281.863 & 211 & & & \\
\hline \multirow[t]{3}{*}{ Statement 5} & Between Groups & .041 & 1 & .041 & & \\
\hline & Within Groups & 394.577 & 210 & 1.879 & .022 & .882 \\
\hline & Total & 394.618 & 211 & & & \\
\hline \multirow[t]{3}{*}{ Statement 6} & Between Groups & 3.391 & 1 & 3.391 & & \\
\hline & Within Groups & 165.533 & 210 & .788 & 4.302 & $.039^{*}$ \\
\hline & Total & 168.925 & 211 & & & \\
\hline \multirow[t]{3}{*}{ Statement 7} & Between Groups & 5.480 & 1 & 5.480 & & \\
\hline & Within Groups & 289.138 & 210 & 1.377 & 3.980 & $.047^{*}$ \\
\hline & Total & 294.618 & 211 & & & \\
\hline \multirow[t]{3}{*}{ Statement 8} & Between Groups & 1.598 & 1 & 1.598 & & \\
\hline & Within Groups & 290.100 & 210 & 1.381 & 1.157 & .283 \\
\hline & Total & 291.698 & 211 & & & \\
\hline \multirow[t]{3}{*}{ Statement 9} & Between Groups & 14.759 & 1 & 14.759 & & \\
\hline & Within Groups & 212.769 & 210 & 1.013 & 14.567 & $.000^{*}$ \\
\hline & Total & 227.528 & 211 & & & \\
\hline \multirow[t]{3}{*}{ Statement 10} & Between Groups & 2.796 & 1 & 2.796 & & \\
\hline & Within Groups & 262.487 & 210 & 1.250 & 2.237 & .136 \\
\hline & Total & 265.283 & 211 & & & \\
\hline \multirow[t]{3}{*}{ Statement 11} & Between Groups & 2.505 & 1 & 2.505 & & \\
\hline & Within Groups & 326.797 & 210 & 1.556 & 1.610 & .206 \\
\hline & Total & 329.302 & 211 & & & \\
\hline
\end{tabular}


Journal of Education Culture and Society No. 1_2021

\begin{tabular}{|c|c|c|c|c|c|c|}
\hline \multirow[t]{3}{*}{ Statement 12} & Between Groups & .064 & 1 & .064 & & \\
\hline & Within Groups & 343.389 & 210 & 1.635 & .039 & .844 \\
\hline & Total & 343.453 & 211 & & & \\
\hline \multirow[t]{3}{*}{ Statement 13} & Between Groups & .174 & 1 & .174 & & \\
\hline & Within Groups & 285.505 & 210 & 1.360 & .128 & .721 \\
\hline & Total & 285.679 & 211 & & & \\
\hline \multirow[t]{3}{*}{ Statement 14} & Between Groups & .298 & 1 & .298 & & \\
\hline & Within Groups & 310.244 & 210 & 1.477 & .202 & .654 \\
\hline & Total & 310.542 & 211 & & & \\
\hline \multirow[t]{3}{*}{ Statement 15} & Between Groups & 1.780 & 1 & 1.780 & & \\
\hline & Within Groups & 350.838 & 210 & 1.671 & 1.065 & .303 \\
\hline & Total & 352.618 & 211 & & & \\
\hline \multirow[t]{3}{*}{ Statement 16} & Between Groups & 1.011 & 1 & 1.011 & & \\
\hline & Within Groups & 349.782 & 210 & 1.666 & .607 & .437 \\
\hline & Total & 350.792 & 211 & & & \\
\hline \multirow[t]{3}{*}{ Statement 17} & Between Groups & 3.679 & 1 & 3.679 & & \\
\hline & Within Groups & 312.599 & 210 & 1.489 & 2.472 & .117 \\
\hline & Total & 316.278 & 211 & & & \\
\hline \multirow[t]{3}{*}{ Statement 18} & Between Groups & 6.152 & 1 & 6.152 & & \\
\hline & Within Groups & 336.528 & 210 & 1.603 & 3.839 & .051 \\
\hline & Total & 342.679 & 211 & & & \\
\hline \multirow[t]{3}{*}{ Statement 19} & Between Groups & 2.561 & 1 & 2.561 & & \\
\hline & Within Groups & 385.968 & 210 & 1.838 & 1.393 & .239 \\
\hline & Total & 388.528 & 211 & & & \\
\hline \multirow[t]{3}{*}{ Statement 20} & Between Groups & 4.116 & 1 & 4.116 & & \\
\hline & Within Groups & 400.841 & 210 & 1.909 & 2.157 & .143 \\
\hline & Total & 404.958 & 211 & & & \\
\hline
\end{tabular}

Source: own research.

The F-values obtained with the stated statements - statement 6, statement 7 and statement 9 show us that there are statistically significant differences between the answers given by the teachers who completed their studies according to the new curriculum and the teachers who completed the studies according to the old one. Given the significance level, these differences are significant at the level of 5\%. Therefore, we can dismiss the null hypothesis for these statements and claim that for the distributions with these statements, there are no presumptions for their normality.

No statistically significant differences were noted with other statements, which means that distributions related to them belong to a larger sample i.e. there are presumptions for their normality. 


\section{CONCLUSIONS}

Following the obtained results of the null-hypothesis by which we assumed that, regardless of the curriculum - new or old - according to which they completed their study, teachers equally assess their personal competencies regarding the integrated education and training of students with developmental disabilities, and therefore, except for three out of twenty statements, it can be accepted as it is. Namely, the differences between the observed groups can be statistically considered significant in only three statements. In this context, the limitation may mean that the results are significant only for the Croatian educational system.

Also, taking into account the possible limitation when interpreting the results related to the sample, a relatively unevenly distributed sample with respect to the completion of the study of the participants, the low reliability of the knowledge scale and a relatively weak sensitivity of the instrument, the obtained results point to relatively small differences in estimates of their own competencies. Namely, generally speaking, teachers who have completed their studies according to the old curriculum are more likely to evaluate their competencies in that context, especially regarding acceptance of children with severe disabilities related to hearing impairment, as well as the use of didactic materials and aids in teaching students with developmental disabilities. On the other hand, teachers who have completed their studies according to the new curriculum considered themselves sufficiently educated to teach students with developmental disabilities, but, in their opinion, they are not offered enough opportunities for further education to work with students with disabilities.

The teachers' responsibility is to enable children with disabilities to learn and thrive in accordance with their abilities and therefore, it is very important to train teachers for such work. The adapted curriculum with favourable educational climate and communication in the classroom environment and with good cooperation with members of the families of students with disabilities would enable educational success (Jurčić, 2012; Radetić-Paić, 2013; Ljubetić, 2014). In this context, it is necessary for teachers to provide support programs from training to practical assistance in their daily work (Bouillet, 2010).

Finally, it is suggested that teaching practice and teaching in pairs will enable students with disabilities to formulate complex questions and discuss them with their mentor. It is important that these students have the ability to respond proactively through critical thinking and building constructive solutions. This can increase their resilience and enable better quality of implementation of inclusion (Drljić \& Kiswarday, 2016).

From all of the above, the assumption follows that the definition and articulation of the necessary competencies are important not only for the professional activities of a profession, but also for the possibility of developing the curricula of the teaching profession (Ricijaš, Huić \& Branica, 2006). The education of teachers to work with children with developmental disabilities must help teachers to assimilate and apply information for the purpose of finding 
alternatives to meet different needs of students (Opara, 2015). According to researches (Stančić, Horvatić \& Nikolić, 2011), teachers are willing to improve their professional skills, but in this context, a constant (self) re-examination is necessary as well. Providing a greater offer of special support programs from teachers' training to practical assistance in the daily work, which is based on a positive education, may improve the subjective experience of teachers and students. Both teachers and students should feel good in class, adding a meaningful value to it. Then, their positive qualities and advantages may be enhanced (Chen, 2018).

Positive education breaks through the traditional education's parochialism on having a bias towards trouble-solving. And finally, it must not be forgotten that the task of a teacher is to make all students, even those who "differ" from the majority, feel accepted and safe. Through various strategies and interventions, a teacher must ensure the smooth and coordinated functioning of the class (Smole \& Vršnik Perše, 2018).

\section{REFERENCES}

[1] Agencija za odgoj i obrazovanje (2013). Strategija stručnog usavršavanja za profesionalni razvoj odgojno-obrazovnih radnika 2014.-2020. [Professional development strategy for professional development of educational workers 2014-2020], Retrieved 3 November 2020, from https:/ / www.nszssh.hr/pdf/Strategija\%20-\%20brosura.pdf

[2] Baguisa, L.R. \& Ang-Manaig, K. (2019). Knowledge, skills and attitudes of teachers on inclusive education and academic performance of children with special needs. People: International Journal of Social Sciences, 4(3), 1409-1425.

[3] Bouillet, D. \& Kudek Mirošević, J. (2015). Students with Disabilities and Challenges in Educational Practice. Croatian Journal of Education, 17(2), 11-26.

[4] Bouillet, D. (2010). Izazovi integriranog odgoja i obrazovanja [Challenges of integrated education]. Zagreb: Školska knjiga.

[5] Chen, Z. (2018). The Origin, Present Situation and Prospect of Positive Education - Based on the Perspective of Positive Psychology. International Journal of Education, Culture and Society, 3(2), 28-33.

[6] Drljić, K. \& Kiswarday, V. (2016). Razvijanje rezilientnosti študentov preko doživljanja izkušnje inkluzije na pedagoški praksi [Developing students' resilience through experiencing the experience of inclusion in pedagogical practice]. Journal of Elementary Education, 9(3), 53-73.

[7] Đuranović, M., Klasnić, I. \& Lapat, G. (2013). Pedagoške kompetencije učitelja u primarnom obrazovanju [Pedagogical competencies of teachers in primary education]. Život $i$ škola, 29 (1), 34-44.

[8] Gallagher, P. \& Malone, M. (2009). Social-Psychological Support Personnel: Attitudes and Perceptions of Teamwork Supporting Children With Disabilities. Journal of Social Work in Disability E Rehabilitation, 8(1), 1-20.

[9] Goldin, N. (2017). Samoprocjena kompetencija učitelja za rad s učenicima s teškoćama u razvoju [Teachers' self-assessment of competence to work with students with disabilities] (Graduation thesis). Pula: Fakultet za odgojne i obrazovne znanosti Sveučilište Jurja Dobrile u Puli.

[10] Igrić, Lj. (2015). Odgojno-obrazovna praksa i različitost. Osnove edukacijskog uključivanja Škola po mjeri svakog djeteta je moguća [Educational practice and diversity] (pp. 77-120). Zagreb: Edukacijsko-rehabilitacijski fakultet Sveučilišta u Zagrebu i Zagreb: Školska knjiga.

[11] Ivančić, Đ. \& Stančić, Z. (2013). Stvaranje inkluzivne kulture škole [Creating an inclusive school culture]. Hrvatska revija za rehabilitacijska istraživanja, 49(1), 139-157.

[12] Jurčić, M. (2012). Pedagoške kompetencije suvremenog učitelja [Pedagogical competencies of a modern teacher]. Zagreb: Recedo d.o.o. 
[13] Kaslow, N. (2004). Competencies in Professional Psychology. American Psychologist, 59(8), 774-781.

[14] Kovač, J., Ščuka, T. \& Čagran, B. (2017). Pogoji za inkluzijo v vzgoji in izobraževanju po oceni ravnateljev [Conditions for inclusion in education according to the assessment of principals]. Journal of Elementary Education, 10(1), 19-29.

[15] Ljubetić, M. (2014). Od suradnje do partnerstva obitelji, odgojno-obrazovne ustanove i zajednice [From cooperation to partnership of family, educational institution and community]. Zagreb: Element.

[16] Milenović, Ž. (2011). Inkluzivno obrazovanje kao posljedica globalizacije [Inclusive education as a consequence of globalization]. Metodički obzori, 12(6), 73-79.

[17] Monsen J.J., Ewing, D.L. \& Kwoka, M. (2014). Teachers' attitudes towards inclusion, perceived adequacy of support and classroom learning environment. Learning Environments Research $17(1), 113-126$.

[18] Nketsia, W. (2016). A cross-sectional study of pre-service teachers' views about disability and attitudes towards inclusive education. International Journal of Research Studies in Education, $6(3), 53-68$.

[19] Opara, B. (2015). Dodatna strokovna pomoč in prilagoditve pri vzgoji in izobraževanju otrok s posebnimi potrebami [Additional professional assistance and adjustments in the upbringing and education of children with special needs]. Ljubljana: Centerkontura.

[20] Radetić-Paić, M. (2018). Competencies for Teachers Working with Children with Developmental Disabilities: Which Direction Should We Take? Zbornik radova 17. Dani Mate Demarina Odgoj i obrazovanje - budućnost civilizacije (pp. 99-112). Petrinja: Učiteljski fakultet Sveučilište u Zagrebu.

[21] Radetić-Paić, Mirjana (2013). Adjustments in working with children with disabilities in educational institutions. Pula: Sveučilište Jurja Dobrile u Puli.

[22] Ricijaš, N., Huić, A. \& Branica, V. (2006). Zadovoljstvo studijem i samoprocjena kompetentnosti studenata nekih pomagačkih profesija [Satisfaction with studies and self-assessment of the competence of students of some auxiliary professions]. Hrvatska revija za rehabilitacijska istraživanja, 42(2), 51-68.

[23] Sadler, I. (2013). The role of self-confidence in learning to teach in higher education. Innovations in Education and Teaching International, 50(2), 157-166.

[24] Smole, A. \& Vršnik Perše, T (2018). Razredniki in vključevanje marginaliziranih skupin učencev v oddelčno skupnost [Class teachers and the integration of marginalized groups of students into the class community]. Journal of Elementary Education, 11(3), 223-250.

[25] Stančić, Z., Horvatić, S. \& Nikolić, B. (2011). Neki aspekti percipirane kompetencije za ulogu učitelja u inkluzivnoj školi [Some aspects of perceived competence for the role of teachers in an inclusive school]. Zbornik radova 5. Međunarodne konferencije o naprednim i sustavnim istraživanjima "Škola, odgoj i učenje za budućnost" (pp. 343-354). Zagreb: Sveučilište u Zagrebu.

[26] Tome, J.M.S. (2021). Special Educational Needs: A New Way of Educating. International Journal of Education, Culture and Society, 6(1), 1-8.

[27] The European Parliament and the Council of the European Union (2006). Recommendation of the European Parliament and of the Council of 18 December 2006 on key competences for lifelong learning. Official Journal of the European Union, L 394/10, 2006/962/EC. Retrieved 2 January 2021, from https:// eur-lex.europa.eu/legal- content/EN/TXT/?uri= celex\%3A32006H0962

[28] Vizek Vidović, V. (2009). Kompetencije i kompetencijski profil u učiteljskoj i nastavničkoj profesiji [Competences and competence profile in the teaching profession]. Planiranje kurikuluma usmjerenog na kompetencije u obrazovanju učitelja i nastawnika (pp. 33-40). Zagreb: Filozofski i Učiteljski fakultet Sveučilišta u Zagrebu.

[29] Zrilić, S. \& Marin, K. (2019). Kompetencije u suvremenoj školi - potrebe prakse iz perspektive učitelja [Competences in the modern school - the needs of practice from the perspective of teachers]. Školski vjesnik, 68(2), 389-400

[30] Zrilić, S. (2013). Djeca s posebnim potrebama u vrtiću i nižim razredima osnovne škole [Children with special needs in kindergarten and lower grades of primary school]. Zadar: Sveučilište u Zadru. 